\title{
Vaccine knowledge in students in Paris, France, and surrounding regions
}

\author{
Guillaume Mellon $M D^{1,2}$, Laurent Rigal $M D^{2}$, Henri Partouche $M D^{2}$, Olivier Aoun $M D^{3}$, Philippe Jaury $M D^{2}$, \\ Nathalie Joannard $M D^{4}$, Jean Paul Guthmann $M^{5}$, Delphine Cochereau $M^{6}{ }^{6}$, Eric Caumes $M D^{1}$, \\ Francois Bricaire $\mathrm{MD}^{1}$, Dominique Salmon-Céron $\mathrm{MD}^{7}$
}

\begin{abstract}
G Mellon, L Rigal, H Partouche, et al. Vaccine knowledge in students in Paris, France, and surrounding regions. Can J Infect Dis Med Microbiol 2014;25(3):141-146.
\end{abstract}

INTRODUCTION: In France, young adults are legally freed from parental authority at the age of 18 years and are, thus, responsible for their own vaccine record. This young adult population is more frequently exposed to vaccine-preventable infectious diseases.

OBJECTIVE: To determine the factors associated with students' knowledge of the interval between two antitetanus boosters and their report of having up-to-date vaccinations.

METHODS: In April 2009, a survey was conducted involving a random sample of students between 18 and 25 years of age eating lunch at university dining facilities in Paris and its suburbs (Ile de France).

RESULTS: Among the 677 students approached, 583 agreed to participate. Only 207 (36\%) of respondents knew the recommended dosing interval between two doses of tetanus vaccine booster (10 years). The majority of students (69\%) reported having up-to-date vaccinations. Declaring having up-to-date vaccinations was significantly associated with having a general practitioner (OR 3.03 [95\% CI 1.69 to 5.55]). Health care students were significantly more likely to know the decennial interval between two antitetanus boosters (OR 2 [95\% CI 1.28 to 3.25]). Most of responding students $(n=519$ [89\%]) believed that vaccines were very useful.

CONCLUSIONS: An overall lack of knowledge of vaccines was observed among this student population. Health care providers, such as GPs and university medical practice staff, who interact with these young individuals have an essential role to promote better vaccination coverage in this population.

Key Words: General practitioner; Students; Tetanus; Vaccine knowledge; Young adults

Tn France, young adults are legally freed from parental authority at the 1 age of 18 years and are, thus, responsible for their own vaccine record. The final booster for diphtheria, tetanus and polio vaccine (dTP) should normally be administered between 16 and 18 years of age, and should be renewed 10 years later as a tetravalent combined vaccine (including the acellular pertussis adsorbed) (1). Within this age bracket (18 to 25 years), booster injections are recommended for measles, mumps, rubella, human papilloma virus (HPV), meningococcal $\mathrm{C}$ and hepatitis $B$ virus $(\mathrm{HBV})$. In France, only recommended vaccinations are publicly funded. Vaccines are prescribed by doctors, and administered by doctors or nursing staff.

This young adult population (18 to 25 years of age) is more frequently exposed to vaccine-preventable infectious diseases such as HPV, meningococcal infections and HBV (2-4). Students should be more

\section{Les connaissances des étudiants de Paris, en France, et des régions avoisinantes au sujet des vaccins}

INTRODUCTION : En France, les jeunes adultes sont légalement libérés de l'autorité parentale à 18 ans et deviennent donc responsables de leur dossier de vaccination. La population de jeunes adultes est davantage exposée aux maladies infectieuses évitables par la vaccination.

OBJECTIF : Déterminer les facteurs associés aux connaissances des étudiants sur l'intervalle entre les deux doses de rappel du vaccin contre le tétanos et sur leur déclaration d'avoir une couverture vaccinale. MÉTHODOLOGIE : En avril 2009, un sondage a été mené auprès d'un échantillon aléatoire d'étudiants de 18 à 25 ans qui, le midi, mangent aux cafétérias universitaires de Paris et des banlieues (Île de France).

RÉSULTATS : Sur les 677 étudiants abordés, 583 ont accepté de participer. Seulement 207 des répondants (36\%) connaissaient l'intervalle recommandé entre deux doses de rappel du vaccin contre le tétanos (dix ans). La majorité des étudiants (69\%) déclarai avoir une couverture vaccinale à jour. Cette déclaration s'associait de manière significative au fait d'avoir un praticien général (RC 3,03 95 \% IC 1,69 à 5,55]). Les étudiants du milieu de la santé étaient considérablement plus enclins à connaître l'intervalle de dix ans entre deux doses de rappel du vaccin antitétanique (RC 2 [95 \% IC 1,28 à 3,25]). La plupart des étudiants répondants ( $\mathrm{n}=519$ [89\%]) croyaient en l'utilité des vaccins.

CONCLUSIONS : Les chercheurs ont constaté une ignorance globale des vaccins au sein de cette population de patients. Les dispensateurs de soins, tels que les praticiens généraux et le personnel médical en milieu universitaire, qui dialoguent avec ces jeunes, ont un rôle essentiel à jouer pour promouvoir une meilleure couverture vaccinale au sein de cette population.

informed about vaccines for their own health, but also because they may soon be making vaccination decisions for their own children. In addition, immunization coverage rates are low in France and other countries (5-10). Furthermore, apart from pediatric and geriatric populations (Appendix 1), there are no data regarding immunization coverage in French students. Information campaigns aiming to improve vaccination coverage in young adults are difficult to conceive without an accurate notion of the knowledge and attitude of this population regarding the different vaccinations. There are very little national and international data in this field. Many authors have published reports on the knowledge and attitude relating to papillomavirus, seasonal or pandemic $(\mathrm{H} 1 \mathrm{~N} 1)_{\mathrm{v} 2} 2009$ influenza virus $(11-18)$, particularly involving health care students (19). However, there are no studies in the international literature investigating vaccine knowledge among all-course students.

${ }^{1}$ Tropical and Infectious Diseases Department, Pitié-Salpêtrière Hospital, Assistance Publique Hôpitaux de Paris; ${ }^{2}$ General Medicine Department,

Paris Descartes University, Sorbonne Paris Cité, Medical School, Paris; ${ }^{3}$ Colmar Joint Medical Center, Colmar; ${ }^{4}$ Direction régionale des

affaires sanitaires et sociales île de France, Paris; ${ }^{5}$ Infectious Disease Department, Institut Nationale de Veille Sanitaire, Saint-Maurice;

${ }^{6}$ Internal Medicine Department, Georges Pompidou European Hospital; ${ }^{7}$ Infectious Diseases Department, Cochin Saint Vincent de Paul Hospital, Assistance Publique Hôpitaux de Paris, Paris, France

Correspondence: Dr Guillaume Mellon, Pitié-Salpêtrière Hospital, Tropical and Infectious Diseases Department, 47/83 boulevard de l'hôpital, 75651 Paris cedex 13, France. Telephone 33-6-63-13-26-88, fax 33-1-42-16-01-66, e-mail guillaume.mellon@psl.aphp.fr 
Our primary objective was to determine the socioeconomic factors associated with students' knowledge of the timing between two antitetanus boosters and with the statement of 'having up-to-date vaccinations' in general. Our secondary objective was to assess students' knowledge of rubella, HBV and papillomavirus vaccines.

\section{METHODS}

In April 2009, a survey was conducted among a random sample of students between 18 and 25 years of age at university dining facilities in Paris and its suburbs (Ile de France). This region was composed of eight departments and inhabited by $10,952,011$ people (18.2\% of the French population) including 599,281 students (26.2\% of French students) (20).

Data were collected using an anonymous questionnaire (Appendix 2) distributed by a trained researcher. Questionnaires consisted of 36 questions related to the social characteristics of the population (age, sex, university department and parental profession), knowledge and behaviour toward vaccination. Vaccination status was, thus, self-reported. Questionnaires were validated before use. Among the 52 university dining facilities of Ile de France, 20 were randomly chosen. Random sampling was computer generated. In each dining facility, at lunch time, a researcher distributed the questionnaire to every 10th student in the queue. Inclusion criteria were: age (18 to 25 years); status as a student; and a good understanding of the questions (evaluated by the researcher after the first five questions). In the absence of eligibility, the following 10th student was chosen. After having explained the terms and conditions of the study, students were considered to have consented to inclusion if they agreed to answer the questionnaire.

The two relevant variables analyzed were: statement of having 'up-to-date vaccines' and knowing the time interval between two boosters of tetanus vaccines. Four groups of variables were created: socioeconomic characteristics of the student; medical follow-up; attitude toward vaccines; and knowledge of vaccines. Logistical regression models were used to identify the items statistically associated with the two relevant variables. For each of the two relevant variables, the variables of the four groups were first tested using univariate analyses. Significant variables (with a threshold of $\mathrm{P}=0.1$ ) were entered in a multivariate model. The final model was obtained at the end of a downward step-by-step selection $(P \leq 0.05)$. Statistical analyses were performed using SAS version 9.2 software (SAS Institute Inc, USA).

The present non-nominative, observational study did not require the approval of an ethics committee, according to French regulations.

\section{RESULTS}

\section{Demographics and medical follow-up (Table 1)}

Among the 677 students who were approached, 583 agreed to participate ( $86 \%$ response rate); 319 were female (male:female ratio 0.83 ) and the mean $( \pm \mathrm{SD})$ age was $21.6 \pm 1.8$ years. Students belonged to the following university departments: natural sciences (26\%); health (19\%); and humanities and arts (17\%). A total of 528 (91\%) students stated they were registered with a general practitioner (GP) and $514(88 \%)$ stated they consulted their GP at least once in the past 12 months.

Attitude and knowledge of students regarding vaccinations (Table 2) Regarding the two relevant variables, 207 (36\%) students knew the tetanus booster interval and 404 (69\%) reported having "up-to-date vaccines". Most students questioned (89\%) believed that vaccines were very useful. Only $11 \%$ of the students were reluctant to be vaccinated. Fear of injections/needles and of side effects were the main reasons cited (35\% and 30\%, respectively). A total of 448 students (77\%) reported "not taking the initiative to be vaccinated". This initiative was taken mostly by the GP for 251 students (43\%) and by parents for 172 students (30\%). Finally, 210 (36\%) discussed vaccination during medical consultation.
The compulsory vaccinations in France (diphtheria, tetanus and polio) were unknown to 330 (57\%) students, while 207 (36\%) knew the time interval recommended between two doses of tetanus vaccine booster.

Three hundred fifty-eight (61\%) students were unaware of the risks prevented by rubella vaccine, and 341 (58\%) and 269 (46\%) did not know the risks related to HBV and HPV infections, respectively.

\section{Variables associated with the correct knowledge of the decennial} tetanus booster (Table 3)

Being a health care student, knowing the compulsory vaccines and reporting having up-to-date vaccinations were significantly associated with knowing the correct antitetanus vaccine decennial interval.

\section{Variables associated with compliance with vaccine schedule} (Table 4)

Reporting up-to-date vaccinations was significantly associated with the following: having a GP; having declared vaccination is useful; having consulted a GP during the previous 12 months; and having identified diphtheria as a mandatory vaccine.

\section{DISCUSSION}

Only 207 (36\%) respondents among a random sample of students in Ile de France knew the correct decennial interval between two tetanus booster doses. Health care students were more likely to know this. Otherwise, the majority (69\%) of students believed that their vaccinations were up to date. The lack of knowledge regarding the decennial interval between two tetanus booster doses observed among our young population may be a cause of poor vaccine coverage in the future. Having seen a GP and having talked about vaccination with him or her was significantly associated with the knowledge of immunization status. Few students $(11 \%)$ reported a reluctance to be vaccinated and most respondents $(89 \%)$ believed that vaccines were very useful. The principal reported deterrents to vaccination were the fear of injections and of side effects. In addition, students remained passive in the decision to vaccinate, with most (73\%) leaving it to their GP or parents. Our results also highlighted a poor knowledge among students about the risks of vaccine-preventable diseases, which are concordant with results of a German study involving medical students (19). For example, regarding HBV, only $26(10 \%)$ students correctly identified cirrhosis and hepatocellular carcinoma as future complications of the infection in our study. Lack of knowledge about HBV-related risks has already been reported in teenagers, students and young adults $(2,4,21,22)$. In a student population, Lohoues Kouacou et al (23) found that the understanding of liver disease was one of the factors highly associated with HBV vaccine coverage. In addition, several studies reported a lack of knowledge among students and young adults regarding the risk for genital HPV infection (12-14,24-27). Our samples corroborated these results.

Moreover, we found few reluctant students, similar to the results of Beytout et al (28). Therefore, in this student population with regular medical follow-up, vaccinations should be easily conducted. Health care providers, such as GPs and university medical practice staff, who interact with these young individuals had an essential role. They promoted preventive actions, such as vaccination, during consultations. Our work demonstrated the key role of GPs, who took the initiative in vaccinating more than two of five students. Similarly, Dempsey et al (29) found that the dTP vaccine coverage rate was correlated to the time investment in vaccination made by GPs. This role would be pertinent given the 2010 measles outbreak among young adults in France (30). This epidemic was responsible for 23,000 cases including six fatalities, 19 neurological complications and $>700$ cases of pneumonia. Apart from children $<4$ years of age, those who were affected the most were those between 20 and 25 years of age, with an incidence of 2.5 per 100,000 population.

However, our study had some limitations. It was restricted to students who used university dining facilities in Paris and its suburbs (Ile de France). The distribution of questionnaires by researchers could have led to answer suggestibility. The replies were declarative, which 
TABLE 1

\section{Sociodemographic characteristics and medical follow-up} of the participants $(n=583)$

\begin{tabular}{|c|c|}
\hline \multicolumn{2}{|l|}{ Sociodemograhic characteristics } \\
\hline Female sex & $319(55)$ \\
\hline Age, years, mean & 21.6 \\
\hline \multicolumn{2}{|l|}{ University department } \\
\hline Humanities and arts & $101(17)$ \\
\hline Health & $112(19)$ \\
\hline Law & $117(21)$ \\
\hline Natural sciences & $149(26)$ \\
\hline Sports & $30(5)$ \\
\hline Technical & $74(13)$ \\
\hline \multicolumn{2}{|l|}{ Year post-high school diploma } \\
\hline 1 & $189(32)$ \\
\hline 2 & $100(17)$ \\
\hline 3 & $127(22)$ \\
\hline 4 & $94(16)$ \\
\hline$\geq 5$ & $73(13)$ \\
\hline Students with French nationality & $527(92)$ \\
\hline Grant holders & $434(74)$ \\
\hline \multicolumn{2}{|l|}{ Paternal profession } \\
\hline Farmer & $6(1)$ \\
\hline Craft worker, shopkeeper, and head of firm & $70(12)$ \\
\hline Manager and high intellectual professions* & $252(43)$ \\
\hline Intermediate professions ${ }^{\dagger}$ & $47(8)$ \\
\hline Employee $^{\ddagger}$ & $71(12)$ \\
\hline Worker§ & $38(7)$ \\
\hline Retired, unemployed & $99(17)$ \\
\hline \multicolumn{2}{|l|}{ Maternal profession } \\
\hline Farmer & $3(0.5)$ \\
\hline Craft worker, shopkeeper and head of firm & $36(6)$ \\
\hline Manager and high intellectual professions* & $167(29)$ \\
\hline Intermediate professions ${ }^{\dagger}$ & $88(15)$ \\
\hline Employee $^{\ddagger}$ & $127(22)$ \\
\hline Worker§ & $14(2.5)$ \\
\hline Retired, unemployed & $148(25)$ \\
\hline \multicolumn{2}{|l|}{ Medical follow up } \\
\hline Students having a general practitioner (GP) & $528(91)$ \\
\hline Students having a health record & $548(94)$ \\
\hline Students who consulted a GP in the past 12 months & $514(88)$ \\
\hline
\end{tabular}

Data presented as $n(\%)$ unless otherwise indicated. ${ }^{*}$ Administration, business or public service head manager, university professor, engineer, medical doctor, lawyer, journalist, artist, officer; ${ }^{\dagger}$ School teacher, nurse, clergyman, technician, foreman, administration, noncommissioned officer, business or public service intermediate supervisor; $¥$ Policeman, soldier, administration employee, secretary, clerk; \$Driver, transporter, agricultural worker, unqualified craft worker or industrial worker

appeared to be the main limitation, in particular with regard to the students' real practices and vaccination status.

On the other hand, the work was performed using two levels of randomization, and researchers were all medical students trained to distribute questionnaires, allowing them to achieve a high response rate. The survey was also an original project previously unreported in the international literature.

Our study could be enlarged to form a national survey to better assess vaccination knowledge of young adults. Finally, although the knowledge level of vaccine status indirectly reflected the immunization coverage of this population, it is necessary to compare our results with those of seroprevalence surveys involving adult populations.
TABLE 2

Attitude and knowledge of students regarding vaccines $(n=583)$

\begin{tabular}{lc}
\hline Attitude toward vaccination & $\mathbf{n ~ ( \% )}$ \\
\hline GP taking initiative for vaccination & $251(43)$ \\
Parents taking initiative for vaccination & $172(30)$ \\
Students requesting a vaccination when consulting GP & $135(23)$ \\
University general practice physician suggesting vaccination & $25(4)$ \\
Students talking about vaccination during consultation & $210(36)$ \\
Students believing vaccines to be very useful & $519(89)$ \\
Students unafraid of vaccination & $405(69)$ \\
Students reluctant to be vaccinated & $66(11)$ \\
Due to fear of injections/needles & $23(35)$ \\
Due to fear of side effects & $20(30)$ \\
Due to fear of developing the disease & $7(11)$ \\
Due to a rare disease & $3(4)$ \\
Due to preference of natural medicine & $2(3)$ \\
Does not know & $11(17)$
\end{tabular}

Knowledge regarding vaccines

\begin{tabular}{lc}
\hline Students knowing compulsory vaccines in France & $253(43)$ \\
Students knowing the tetanus booster interval* & $207(36)$ \\
Answers regarding the risks prevented by rubella vaccine & $225(39)$ \\
Teratogenicity & $174(77)$ \\
Sterility & $24(11)$ \\
Rubella & $18(8)$ \\
Other & $9(4)$ \\
Answers regarding the risks prevented by HBV vaccine & $242(42)$ \\
Hepatitis B & $143(60)$ \\
Sexually transmitted infections & $43(18)$ \\
Hepatocellular carcinoma & $18(7)$ \\
Hepatic cirrhosis & $8(3)$ \\
Other & $30(12)$ \\
Answers regarding the risks prevented by HPV vaccine & $314(54)$ \\
Cervical cancer & $226(72)$ \\
Uterine cancer & $59(19)$ \\
Unspecified cancer & $10(3)$ \\
Other & $19(6)$ \\
Students declaring a mass and individual vaccine protection & $524(92)$ \\
Students reporting up to date vaccinations* & $404(69)$ \\
Vaccine status lack of knowledge is due to lack of interest & $118(66)$ \\
Vaccine status lack of knowledge is due to lack of time & $21(12)$ \\
\hline
\end{tabular}

*The two relevant variables. GP General practitioner; HBV Hepatitis $B$ virus; HPV Human papilloma virus

\section{CONCLUSION}

We observed a lack of knowledge about the tetanus booster interval and the risks of vaccine-preventable diseases. We also found that declaring an up-to-date vaccination status was significantly associated with having a GP. Thus, it should be impressed on GPs to educate patients effectively on the importance of vaccination, especially students. These results also showed the importance of informing students on vaccine-preventable diseases to improve their knowledge and, therefore, vaccine uptake, which should continue through to adulthood. In addition, mass-media information campaigns using the Internet, television, radio, newspapers, movie theaters, street and public transportation poster signs would also play an essential role. Finally, educational lectures on vaccination and vaccine-preventable diseases in schools from kindergarten to grade 12 should be considered.

DISCLOSURES: The authors have no conflicts of interest to declare. 
TABLE 3

Variables associated with the correct knowledge of the decennial tetanus booster in the 583 participants

\begin{tabular}{|c|c|c|c|c|}
\hline \multirow[b]{2}{*}{ Variable } & \multicolumn{4}{|c|}{ Decennial tetanus booster } \\
\hline & $\mathbf{P}^{*}$ & OR & $95 \% \mathrm{Cl}$ & $\mathbf{P}^{\dagger}$ \\
\hline \multicolumn{5}{|l|}{ Sociodemographic characteristics } \\
\hline Studying health care & $<0.001$ & 2 & $1.28-3.25$ & 0.002 \\
\hline Male sex & 0.148 & & & \\
\hline Having at least one unemployed parent & 0.151 & & & \\
\hline$>3$ years post-high school diploma & 0.066 & & & \\
\hline Having a grant & 0.033 & 0.4 & $0.14-0.65$ & 0.026 \\
\hline \multicolumn{5}{|l|}{ Medical follow-up } \\
\hline Students having a general practitioner & 0.49 & & & \\
\hline Students who consulted a general practitioner in the past 12 months & 0.172 & & & \\
\hline \multicolumn{5}{|l|}{ Attitude toward vaccination } \\
\hline Believing vaccination is useful & 0.174 & & & \\
\hline \multicolumn{5}{|l|}{ Knowledge regarding vaccines } \\
\hline Knowing compulsory vaccines & $<0.001$ & 1.7 & $1.15-2.33$ & 0.006 \\
\hline Identifying diphtheria vaccine as a compulsory vaccine & 0.073 & & & \\
\hline Identifying pertussis vaccine as a compulsory vaccine & 0.003 & 2.1 & $1.29-3.33$ & 0.003 \\
\hline Identifying varicella vaccine as a compulsory vaccine & 0.034 & 0.38 & $0.18-0.77$ & 0.008 \\
\hline
\end{tabular}

${ }^{*}$ Univariate analysis; ${ }^{\dagger}$ Multivariate analysis

TABLE 4

Factors associated with reporting "having up-to-date vaccinations" in the 583 participants

\begin{tabular}{|c|c|c|c|c|}
\hline \multirow[b]{2}{*}{ Variable } & \multicolumn{4}{|c|}{ Reporting having up-to-date vaccinations } \\
\hline & $\mathbf{P}^{*}$ & OR & $95 \% \mathrm{Cl}$ & $\mathbf{P}^{\dagger}$ \\
\hline \multicolumn{5}{|l|}{ Sociodemographic characteristics } \\
\hline Studying health care & 0.005 & 1.7 & $0.11-3.25$ & 0.019 \\
\hline Male sex & 0.201 & 0.7 & $0.46-0.96$ & 0.029 \\
\hline Having at least one unemployed parent & 0.011 & 0.7 & $0.42-0.98$ & 0.01 \\
\hline$>3$ years post-high school diploma & 0.011 & 0.8 & $0.65-1.02$ & 0.015 \\
\hline \multicolumn{5}{|l|}{ Medical follow up } \\
\hline Students having a general practitioner & $<0.001$ & 3 & $1.69-5.55$ & $<0.001$ \\
\hline Students who consulted a general practitioner in the past 12 months & $<0.001$ & 1.9 & $1.04-3.57$ & 0.004 \\
\hline \multicolumn{5}{|l|}{ Attitude toward vaccination } \\
\hline Believing vaccination is useful & 0.003 & 2.2 & $1.29-3.84$ & 0.003 \\
\hline Being reluctant to get vaccinated & 0.088 & & & \\
\hline Identifying varicella vaccine as a compulsory vaccine & 0.948 & & & \\
\hline
\end{tabular}

*Univariate analysis; ${ }^{\dagger}$ Multivariate analysis

\section{APPENDIX 1}

There are some data regarding children and the elderly but they do not correspond to our population.

In the French pediatric population:

- Diphtheria, pertussis and tetanus vaccination: At two years of age, $98.7 \%$ had already completed the first three-shot series and 91.3\% had received the booster dose (fourth shot) in 2011.

- Pertussis vaccination: At two years of age, $98.4 \%$ had already the first three-shot series and $90.5 \%$ had received the booster dose (fourth shot) in 2011.
- Hepatitis B virus vaccination: At two years of age, $74.2 \%$ already completed the three-shot series in 2011.

- Measles-mumps-rubella : At two years of age, $67.3 \%$ completed the two-shot series in 2011

In the geriatric population: dTP coverage is $44 \%$ after 65 years of age. There are no data concerning national vaccination coverage in French students. This is why we conducted our survey. 


\section{APPENDIX 2}

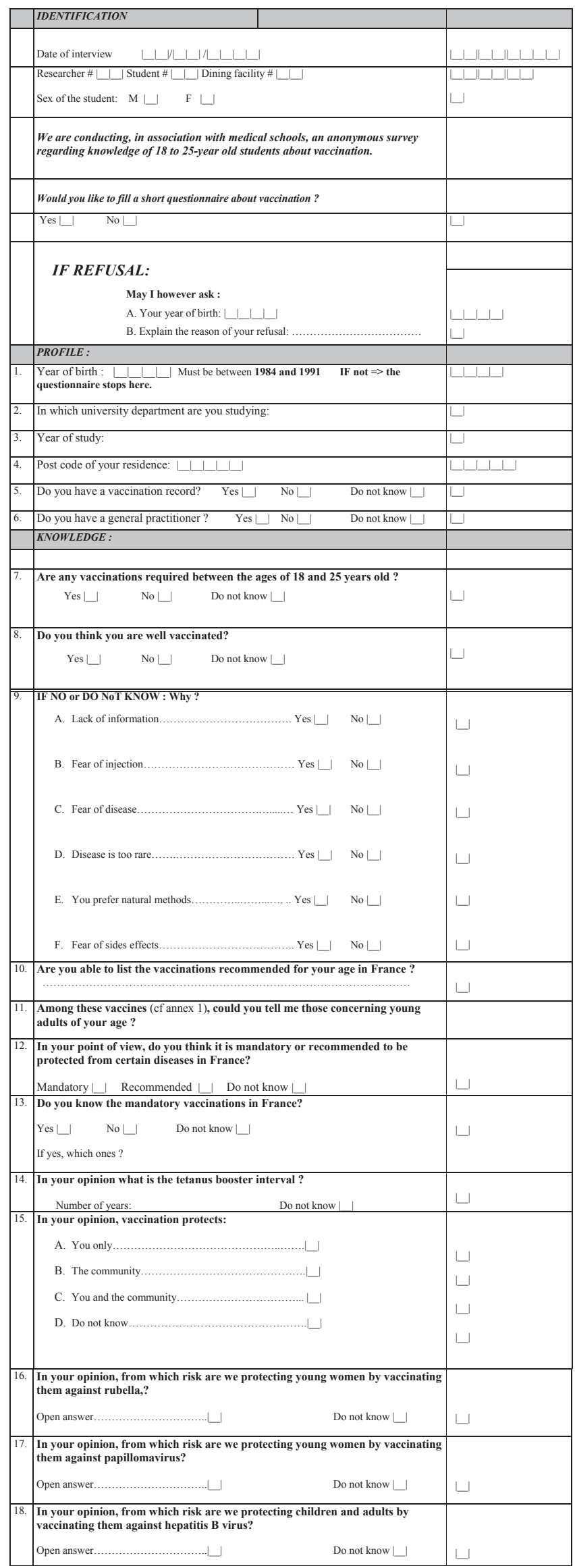

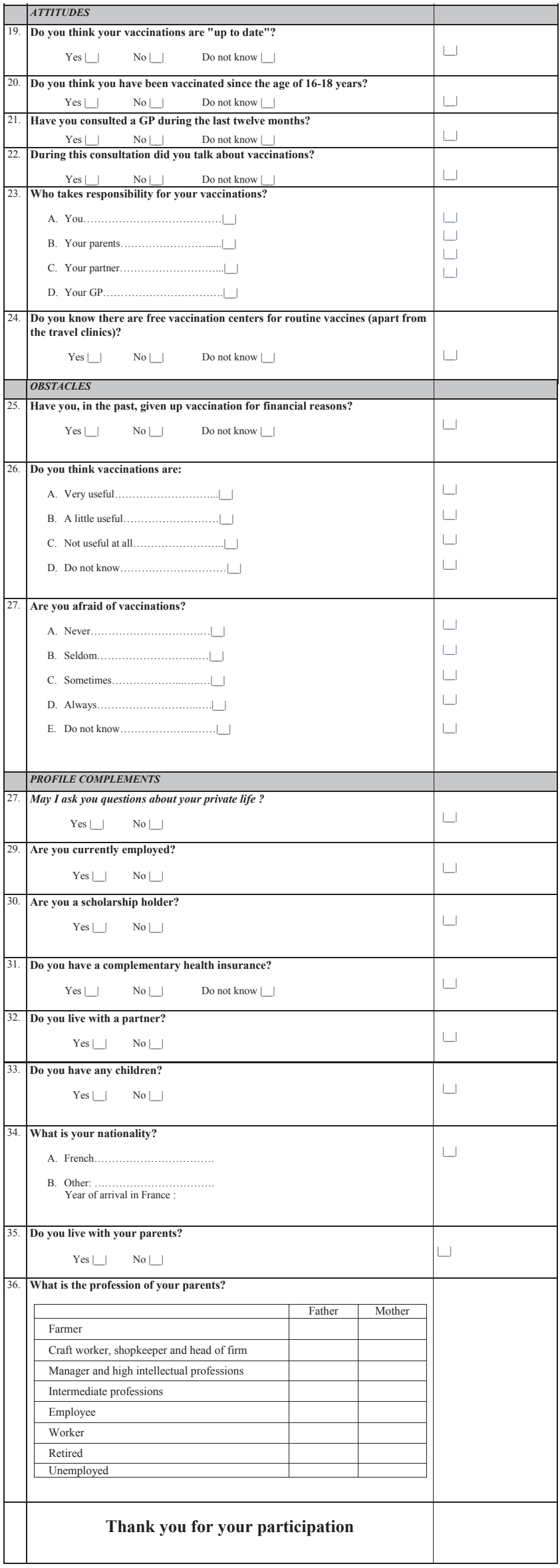




\section{REFERENCES}

1. Floret D. 2011 vaccination schedule and recommendations from the " Haut Conseil de la santé publique » in France 2011. <www.invs.sante. fr/beh/2011/10_11/beh_10_11_2011.pdf> (Accessed March 2012).

2. Slonim AB, Roberto AJ, Downing CR, et al. Adolescents' knowledge, beliefs, and behaviors regarding hepatitis B: Insights and implications for programs targeting vaccine-preventable diseases. J Adolesc Health 2005;36:178-86.

3. Vallin J, Meslé F. Les causes de décès en France de 1925 à 1978. Présentation d'un Cahier de l'INED. 1988. <www.persee.fr/web/ revues/home/prescript/article/pop_0032-4663_1988_ num_43_1_17017> (Accessed March 2012).

4. Moore-Caldwell SY, Werner MJ, Powell L, Greene JW. Hepatitis B vaccination in adolescents: Knowledge, perceived risk, and compliance. J Adolesc Health 1997;20:294-9.

5. Torda AJ. Vaccination and screening of medical students: Results of a student health initiative. Med J Aust 2008;189:484-6.

6. Murray DL, Lynch MA. Determination of immune status to measles, rubella, and varicella-zoster viruses among medical students: Assessment of historical information. Am J Public Health 1988;78:836-8.

7. Schmid K, Wallaschofski H, Drexler H. Student health policy of a German medical school - results of a cross sectional study concerning students' immunity to vaccine-preventable diseases. Int J Hyg Environ Health 2004;207:595-600.

8. Baer G, Bonhoeffer J, Schaad UB, Heininger U. Seroprevalence and immunization history of selected vaccine preventable diseases in medical students. Vaccine 2005;23:2016-20.

9. Guthmann J-P, Fonteneau L, Antona D, Lévy-Bruhl D. Factors associated with tetanus vaccination coverage in adults in France and with knowledge of vaccination status. Med Mal Infect 2010;40:560-7.

10. Miller BL, Kretsinger K, Euler GL, Lu P-J, Ahmed F. Barriers to early uptake of tetanus, diphtheria and acellular pertussis vaccine (Tdap) among adults-United States, 2005-2007. Vaccine 2011;29:3850-6.

11. Rehmani R, Memon JI. Knowledge, attitudes and beliefs regarding influenza vaccination among healthcare workers in a Saudi hospital. Vaccine 2010;28:4283-7.

12. Burchell AN, Winer RL, de Sanjosé S, Franco EL. Chapter 6: Epidemiology and transmission dynamics of genital HPV infection. Vaccine 2006;24(Suppl 3):S3/52-61.

13. Brewer NT, Fazekas KI. Predictors of HPV vaccine acceptability: A theory-informed, systematic review. Prev Med 2007;45:107-14.

14. Agius PA, Pitts MK, Smith AMA, Mitchell A. Human papillomavirus and cervical cancer: Gardasil vaccination status and knowledge amongst a nationally representative sample of Australian secondary school students. Vaccine 2010;28:4416-22.

15. Suresh PS, Thejaswini V, Rajan T. Factors associated with 2009 pandemic influenza $A$ (H1N1) vaccination acceptance among university students from India during the post-pandemic phase. BMC Infect Dis 2011;11:205.

16. Giambi C, Donati S, Declich S, et al. Estimated acceptance of HPV vaccination among Italian women aged 18-26 years. Vaccine 2011;29:8373-80.

17. Loulergue P, Moulin F, Vidal-Trecan G, et al. Knowledge, attitudes and vaccination coverage of healthcare workers regarding occupational vaccinations. Vaccine 2009;27:4240-3.

18. Shahrabani S, Benzion U, Yom Din G. Factors affecting nurses' decision to get the flu vaccine. Eur J Health Econ 2009;10:227-31.

19. Wallaschofski H, Drexler H, Schmid K. What do medical students know about their vaccination status and how effective is their vaccine protection? Dtsch Med Wochenschr 2005;130:1429-33.

20. L'enseignement supérieur en Ile de Franc - Atltas régional. $<$ http://media.enseignementsup-recherche.gouv.fr/file/78/2/3782. pdf $>$ (Accessed March 2012).

21. de Melo GB, Gontijo Filho PP. Survey of the knowledge and practice of infection control among dental practitioners. Braz J Infect Dis 2000;4:291-5.

22. Hwang JP, Huang CH, Yi JK. Knowledge about hepatitis B and predictors of hepatitis B vaccination among Vietnamese American college students. J Am Coll Health 2008;56:377-82.

23. Lohoues Kouacou MJ, Biekre R, Allah-Kouadio E. Hépatite virale B en milieu universitaire : onnaissance et couverture vaccinale. Gastro enterologie clinique et biologique 2009;33:A227.

24. Walsh CD, Gera A, Shah M, Sharma A, Powell JE, Wilson S. Public knowledge and attitudes towards human papilloma virus (HPV) vaccination. BMC Public Health 2008;8:368.

25. Donders GGG, Gabrovska M, Bellen G, et al. Knowledge of cervix cancer, human papilloma virus (HPV) and HPV vaccination at the moment of introduction of the vaccine in women in Belgium. Arch Gynecol Obstet 2008;277:291-8.

26. Brotherton JML, Leask J, Jackson C, McCaffery K, Trevena LJ. National survey of general practitioners' experience of delivering the National Human Papillomavirus Vaccination Program. Sex Health 2010;7:291-8.

27. Jestin C. Perception de la prévention du cancer du col de l'utérus : étude qualitative auprès de jeunes filles et mères d'adolescentes. INPES. $\left(n^{\circ} 103\right)$.

28. Beytout J, Denis F, Giet R, Allaert FA. Regional variations of adult population vaccinal status. Med Mal Infect 2004;34:460-8.

29. Dempsey AF, Cowan AE, Broder KR, Kretsinger K, Stokley S, Clark SJ. Adolescent Tdap vaccine use among primary care physicians. J Adolesc Health 2009;44:387-93.

30. Benkimoun P. Outbreak of measles in France shows no signs of abating. BMJ 2011;342:d3161. 


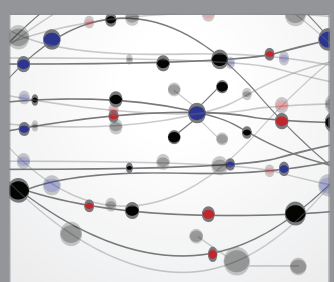

The Scientific World Journal
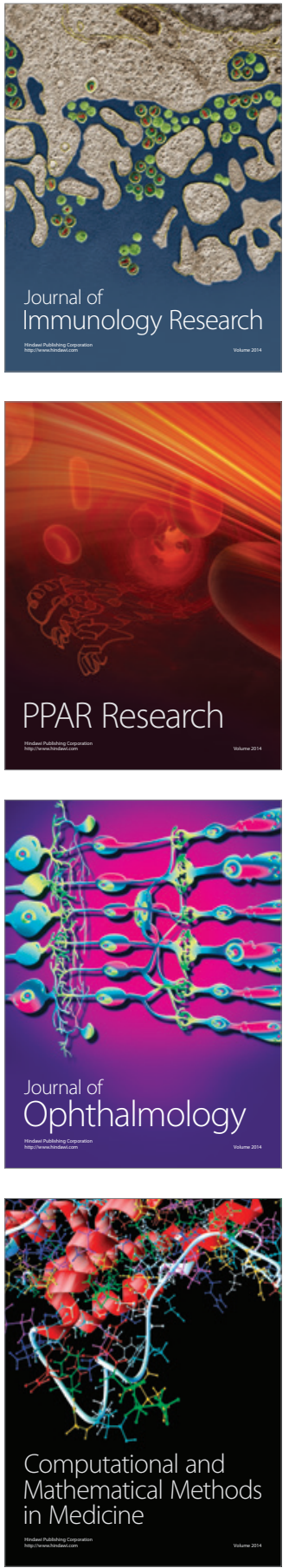

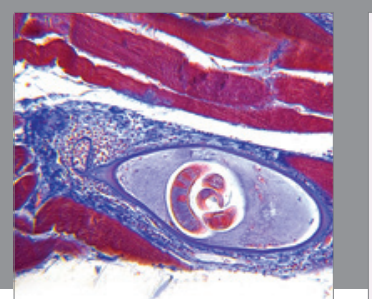

Gastroenterology Research and Practice

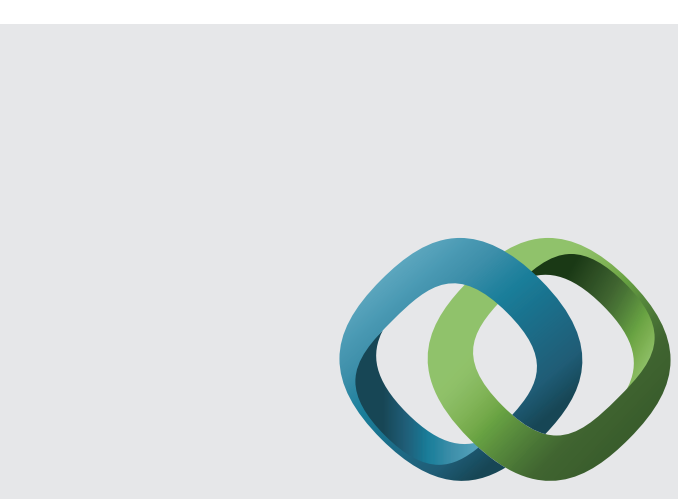

\section{Hindawi}

Submit your manuscripts at

http://www.hindawi.com
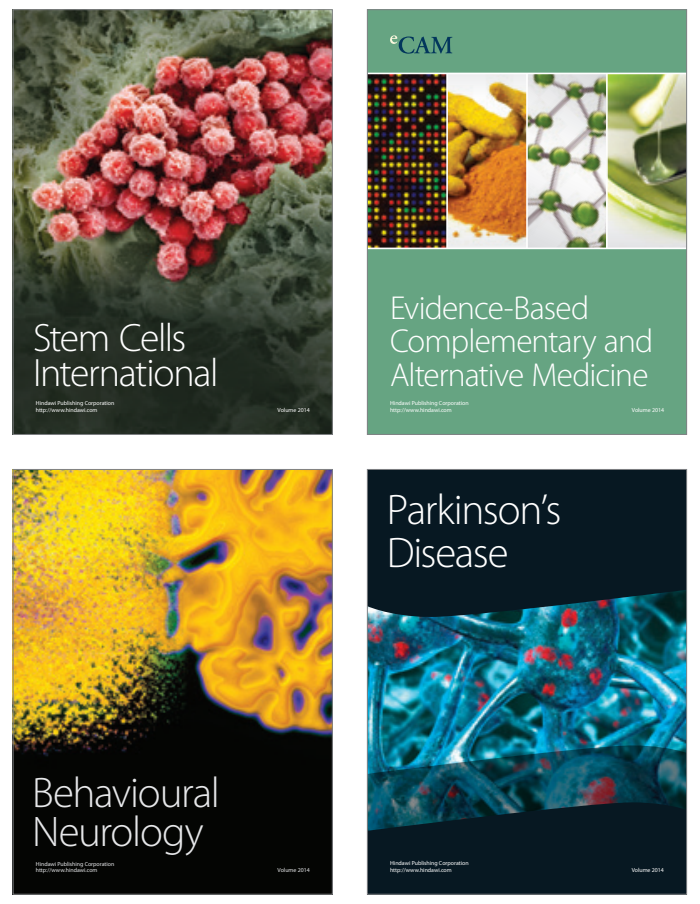
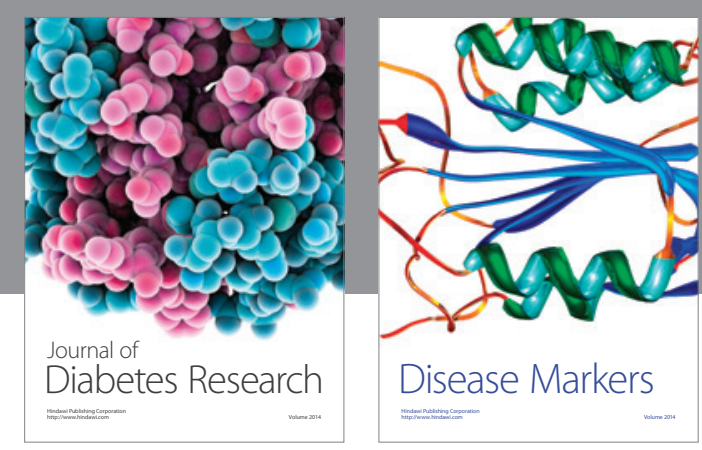

Disease Markers
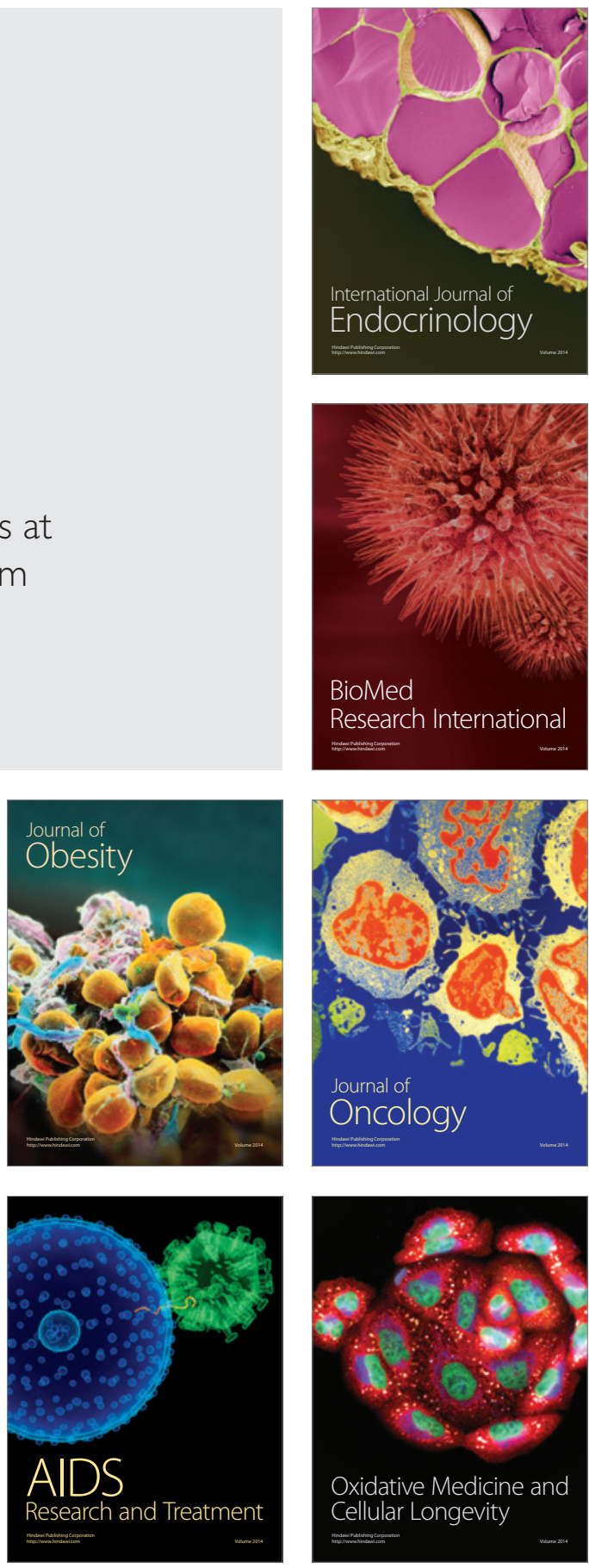